\title{
Impact of Training on Earnings: Evidence from Pakistani Industries
}

\author{
Zainab Javied \\ Fatima Jinnah Women University, Rawalpindi \\ E-mail: zainab_javied2000@yahoo.com \\ Asma Hyder (Corresponding author) \\ Assistant Professor \\ NUST Business School, Islamabad \\ E-mail: baloch.asma@gmail.com
}

\begin{abstract}
Training and skills development play a vital role in individual's productive capacity and are integral part of Human Resource Development (HRD). This study aims to examine the role of training in determination of wages. By utilizing the cross-sectional data from Labor Force Survey 2005-06, results have shown that training is not significant in the determination of wages, which shows the poor quality of training in the overall economy. Results were obtained by Ordinary Least Square (OLS) technique. However, schooling and other demographic variables have expected signs and magnitudes. The recommendations of the study based on empirical findings are toward technical education and vocational training institutions; they should ideally have to devise their technical education and vocational training exactly according to the requirements of industry. Empirical results also emphasize to improve the quality of training.
\end{abstract}

Keywords: Wages, Investment in human capital, Training, Cross-section data, Industries, Developing country

\section{Introduction}

Training in general and skills development in particular, not only play a vital role in individual, organizational and overall national economic growth but are integral part of Human Resource Development (HRD). Empirical literature on the subject topic suggests that human capabilities can be improved through better education and training [Haq (2002)]. Education and training are indispensable instruments for improving labour mobility, adaptability and productivity, thus contributing to enhancing firms' competitiveness and redressing labour market imbalances [Cailods (1994)].

The demand for trained and technically educated human resource rises with every step towards industrialization and modernization of production units and work premises. The development of services sector, that invariably follows industrialization and modernization, requires mid-level human resource duly possessing entrepreneurial, secretarial and other skills. Over time these countries have invested heavily in both physical and human capital.

As with capital and skill, there are also complementarities between technology and skill. Technological changes have shifted demand toward higher skills in the labour force [World Bank (2002)]. The acceleration of technical change in recent decades has been complemented by greater numbers of workers with higher skill. New technologies are knowledge and skill intensive, and there is a need to train people to work accordingly.

The relationship between on-the-job training and wage growth has been the subjects of many researchers have sought to determine the validity of the predications of the theory of human capital. A well organized education system and a more educated labour force can act to attract globalize financial capital [O'Connor and Lunati (1999)]. The present study is primarily based on following hypothesis:

Hypothesis 1- Pakistani industries do not have significantly trained workers

Hypothesis 2- There is significant effect of training on wages in Pakistani industries.

Hypothesis 3- There is positive effect of the interaction terms on earnings (Gender*training, Location of enterprise*training, Schooling*training). 
The organization of the study is now outlined: next section describes the historical background of the topic in the country. Section three through light on empirical evidence and leads toward data and methodology section. Conclusion and policy implication are followed by discussion on empirical results.

\section{Historical Background}

Pakistan inherited a weak Vocational Education and Training (VET) base at the time of independence in 1947, this argument has been supported by [Munir (2002), Shah (2003), Akram and Khan (2007)]. During the period 1950-2002, hundreds of middle, secondary and higher level vocational education and training schools, polytechnic institutes, colleges and universities in government and private sector have been set up. However in the Pakistani context, the term technical education refers to post secondary courses of study and practical training aimed at preparation of technicians to work as middle level supervisory staff; where as the vocational education refers to as lower level education and training for the preparation of semi skilled and skilled workers in various trades. At present a number of departments such as education, labour and human resources, industries, social welfare and agricultural departments are involved in TVE. The Federal Ministry of Education is basically responsible for policy planning, coordination of standards and curriculum development for post secondary technical education provided in colleges of technology and polytechnic institutes under the education department. Different prominent training policies in the country are discussed in order.

In late 1950s, the government of Pakistan put education on its development agenda. Dignity of labour and vocational education and training was declared as the cornerstone of this policy to make the best possible use of human and capital resources of the country.

The Education Policy 1972-80 duly recognized the concept of dignity of labour by advocating for trained human resources in different vocational trades. Under this policy, vocational education and training workshops were opened up at middle level in schools where students were imparted vocational training in weaving, book-binding, wood work, black-smithy, leather-work, food preservation, child care, home management, electricity and agriculture in accordance with the local needs. During 1981-91 is the worst time period in terms promotion of vocational training in the country. During this period nothing special was added to the count of vocational education and training in the existing vocational education schools and colleges rather a number of polytechnic institutes and colleges were closed to avoid the student movement against the dictatorial government.

The successive government after Zia's regime; Education Policy (1992-2002) was thoroughly analyzed and the need for the vocational and technical education was felt. The policy admitted the poor quality of vocational education and training (VET) institutes/colleges in the country but their curriculum does not subscribe to the job market owing to new human resources market. Training of semi-literate dropouts also remains a problem. The Education policy 1992-2002 led to setting up of a network of technical teachers training institutes, one each in all the four provinces of Pakistan, linking them with the National Teachers Training College at federal level. One vocational subject was declared compulsory part of general education. Even while Education Policy 1992-2002 was under implementation, a new National Education Policy 1998-2010 was formulated to cater the needs of the time by incorporating new trends in the market oriented education system.

The National Education policy 1998-2010 duly recognized that sustainable socioeconomic development is not possible by mere capital investment unless it is reinforced with proper supply of adequately trained scientific and technical human resources. The policy document admits that there has been a greater increase in facilities for general education in the country over the years but adequate facilities and opportunities has not been provided for promotion of vocational education and training (VET). Another prominent scheme is Technical Education Project (1996-2003) initiated by the Federal Ministry of education with the assistance of the Asian Development Bank. These are the few attempts made by the government to meet the demands of modern labor market but how much this objective is achieved is analyzed in forth coming sections.

There are few studies conducted in Pakistan to examine the impact of training, the present study is thus an extension in previous empirical work. Hussain et al., (1994) concluded that T \& V (Training and Visit extension system) has increased the quantity but not the quality of extension contact and this, in turn, has increased farmers' knowledge and adoption of technology. However, the overall impacts have been small relative to those observed in a similar area in India. Anderson, Gershon, and Sushma (2006) discusses in detail the origins and evolution of the Training and Visit $(\mathrm{T} \& \mathrm{~V})$ extension system, which was promoted by the World Bank in 1975-98 in over 50 developing countries. The paper identifies some of the challenges faced by the $\mathrm{T} \& \mathrm{~V}$ approach as being typical of a large public extension system, where issues of scale, interaction with the agricultural research systems, inability to attribute benefits, weak accountability, and lack of political support tend to lead to incentive problems among staff and managers of extension, and limited budgetary resources. According to Hyder (2007) the wage gap among the employees of State Owned Enterprises is lowest for different educational levels. However in her study the training coefficient in all the three sectors is insignificant 


\section{Data Description}

Data that I used for my paper is taken from labour Force Survey (LFS) 2005-06. It is a regular feature of the Federal Bureau of Statistics (FBS) since July, 1963. These data provides comprehensive information not only on the unemployed persons but also on many characteristics of employed persons. The Labor Force Survey constitutes henceforth be quarterly as well as annual sample enquiry. However our model specification includes monthly wages as dependent variable and explanatory variables include demographic and human capital variables.

The summary statistics are given in Annexure Table 1.2 and few important statistical facts are in order. Starting from agriculture industry in which 643 employees are engaged, it is found that mean age of the employees is 32 years. Among the total employed individual in agriculture sector 95 percent are male and 65 percent are married. Summary statistics show very low human capital both in terms of schooling and training is found in this sector.

Our sample comprises of only 51 employees working in mining and quarrying industry. It is found that mean age of the employees is 35 years in this industry. Only 2 percent of total workers in this industry are female. The proportion of married individuals is $70 \%$ in this industry. Hardly $2 \%$ workers are trained in mining and quarrying sector.

Manufacturing industry comprises of 3245 employees. It is found that mean age of the employees is 30 years. $94 \%$ of the employees engage in this industry are male. Average years of schooling of employees in the industry have twelve years of schooling; however it is 14-16 years of schooling in electricity, gas and water industry. Summary statistics of workers employed in construction industry are almost similar to manufacturing industry.

There are 1387 employees working in transport industry and mean age of workers is 35 years. Average years of schooling are 12 years and a very negligible proportion represent the trained workers. The highest years of schooling is found to be in finance industry, which shows on average the employees have masters' degrees.

\section{The Analytical Framework of the Model}

To analyze the issue for labor market in Pakistan Ordinary Least Square method is used. Log of monthly wages is regressed upon the variables described in above section. Following equation specifically describe the functional form in detail:

$$
\begin{aligned}
& \operatorname{lnmwage}_{\mathrm{ij}}=\beta 0+\beta_{1} \text { age }_{\mathrm{ij}}+\beta_{2} \text { age }_{\mathrm{ij}}{ }^{2}+\beta_{3} \text { male }_{\mathrm{ij}}+\beta_{4} \\
& \text { ms }_{\mathrm{ij}}+\beta_{5} \text { loct }_{\mathrm{ij}}+\beta_{6} \text { schooling }_{\mathrm{ij}}+\beta_{7} \operatorname{Training}_{\mathrm{ij}}+\beta_{8} \operatorname{Schtrain}_{\mathrm{ij}}+ \\
& \beta_{9} \text { gentrain }_{\mathrm{ij}}+\beta_{1 \mathrm{o}} \operatorname{loctrain}_{\mathrm{ij}}+\mathrm{u}_{\mathrm{ij}}
\end{aligned}
$$

Where:

$i=$ ith individual in the labor market

$j=1-9$ are the nine industries according to international standard industrial classification.

And ' $u$ ' is error term which is normally distributed between zero mean and constant standard deviation.

Since main theme of the paper is to explore the impact of training on wages, thus to due to our particular emphasize on training three interactive variables are also introduced. These three integrative variables are 'Schtrain', 'gentrain', 'loctrain'; the variables shows the interaction of training with schooling, gender and location of enterprise respectively. The estimated results are presented in the next section.

\section{Results and Discussion}

The empirical results of all nine industries are discussed in order.

\subsection{Agriculture}

The result show that age in agriculture sector is significant and has a positive relationship with the log of monthly wage and shows that increase of one year in age of the workers of the agriculture industry, their monthly wage increases by .049 percentage points. The workers in this sector maximize their earnings at the age of 38 years. This is very young age to maximize the earnings, the reason may be that in agriculture sector maximum wages are not very high and saturation point arrives at an early age.

Level of education plays very important role in this sector. The result shows that education in agriculture industry is significantly and positively related to log of monthly wages. $1 \%$ increase in the education level of the employees will bring .035 percentage points increase in the wages. Economists regard education as both consumer and capital good because it offers utility to a consumer and also serves as an input into the production of other goods and services. Agriculture forms the backbone of Pakistan's economy. The sector contributes 25 percent of the country's gross domestic product (GDP) and employs almost half of its labor force. For these reasons, agricultural productivity growth is a key factor in Pakistan's economic development and poverty alleviation objectives. Thus to educate the workers in this sector should be the government priority. 
Training is insignificant. 'Location of enterprise' in agriculture sector is significant at $5 \%$ and has a positive relationship with the log of monthly wage. The first two interactive terms are dropped from the model due to negligible number of observations in these categories. The results are consistent with Hussain, Byerlee and Heisey (1994) for examining the quantitative evidence on the impact of the Training and Visit (T \& V) extension system in the irrigated Punjab of Pakistan.

\subsection{Mining and Quarrying}

The result show that age in mining and quarrying sector is insignificant, and has no effect on monthly wages for employees in this sector. The employees working in the mining and quarrying industries maximize their wages at the age of 48 years approximately. Marital status is insignificant. However, gender is significant with a negative sign. The results show that being female increases the wages as compared to male workers. It is also very important to mention here that in this sector $98 \%$ are male and only $2 \%$ are female, thus there is the chance that this small proportion of female in our sample may be skewed toward highly paid female workers.

The variable education in mining and quarrying industry is positively and significantly related to log of monthly wages. With every additional year of schooling, the monthly wage increases by .065 percentage points. Training is dropped in estimation due to few observations in this category and pulls the attention towards low trained individuals in this industry. Another fact is that mining and quarrying is an industry which requires training due to many risks involved in it.

\subsection{Manufacturing}

The result show that age in manufacturing sector is significantly related to log of monthly wages. Age square is significant and has negative sign which confirms an inverted U-shaped relationship between age and earnings. The employees working in the manufacturing industries maximize their wages at the age of 52 years approximately.

Schooling is a significant variable with a positive effect on wages. There is also evidence of huge disparities in education attainment in this sector. Robert (1991) developed a human capital model which shows that education and the creation of human capital was responsible for both the differences in labour productivity and the differences in overall levels of technology. The manufacturing sector of any country bears significant importance. Pakistan's exports concentrated largely in textile and semi-manufactures, the country needs to strengthen this sector in terms of education and training.

Location of enterprise is also positively related with wages of the employees. Results show that employed in the establishments located in urban areas are more advantaged than the employed in the industries of rural areas. Kagundu and Pavlova (2007) analyzed that the urban sector has much better developed labor markets that resemble labor markets in developed economies. Labor unions are much more active in urban formal markets compared to rural relatively informal labor markets. Low level of education and exposure to the relevant labor rights legislations could imply more exploitation by relatively more knowledgeable employers.

\subsection{Electricity, Gas and Water}

Schooling has a positive and significant effect on wages. With the increase in level of education wages of the employees also increases in the electricity, gas and water sector. Training is significant and its effect on wages seems very high in estimated co-efficient. Significance of training coefficient in this particular industry shows the importance and good quality of training in this sector. The interactive term "Location*training" has significant and positive effect on wages.

\subsection{Construction}

The result show that age in construction sector is significantly related to log of monthly wages. The employees working in the construction industries maximize their wages at the age of 52 years. Marital status has significant and positive effect on wages. Schooling is again significant like other industries. Training is insignificant which shows the poor quality of training in the sector.

\subsection{Whole Sales, Retail Trade, Restaurants and Hotels}

The result show that age in whole sale sector is significantly related to log of monthly wages, however the wage maximizing age is 45 years approximately. The result shows that marital status in whole sale sector is significantly related to $\log$ of monthly wages. Schooling variable has its expected sign and magnitude.

Location if enterprise appears to be an important determinant of wages in this particular industry. Estimated coefficient shows that employed in such enterprises located in urban areas are more advantaged than those employed in rural areas.

\subsection{Transport, Storage and communications}

The result show that age in transport industry is highly significant at $1 \%$ and has a positive relationship with the $\log$ of monthly wage. School coefficient shows that increase of an additional year of schooling will bring .045 percentage 
points increase in the wages. Transport is an important sector of Pakistan's economy as it contributes about $10 \%$ to the Gross Domestic Product and over 17 percent to the Gross Capital Formation. It is estimated that about 2.3 million people ( $6 \%$ of the total employed labor force of Pakistan) earn their livelihoods from this sector. Transport consumes $35 \%$ of the total commercial energy annually and receives $20-25 \%$ of the annual federal public sector development funds. Marital Status is significant and estimated coefficient shows that being married increases the wage by .0931 percentage points. Location of establishment is positively related with wages of the employees. Training is insignificant in this sector.

\subsection{Financing, Insurance, Real Estate and Business services}

The result show that age in finance and insurance industry is highly significantly related to log of monthly wages. Age square is significant and has negative sign also shows that employees working in the finance industries maximize their wages at the age of 49 years approximately.

School is a significant variable with a positive effect on wages. The services sector plays a vital role in sustaining the growth of Pakistan's economy, with a share of 53.3 percent in GDP, and 44 percent (which includes construction sector) in employed labour force. Banks, DFIs and insurance companies, account for 98 percent of value added in this sector. The finance and insurance sector comprises State Bank of Pakistan, all scheduled (domestic and foreign banks) development financial institutions (DFIs), all insurance (life and general) companies, Modaraba/leasing companies, moneychangers and stock exchange brokers. The financial sub-sector consists of all resident corporations principally engaged in financial intermediations or in auxiliary financial activities related to financial intermediation. The interactive term "School*training" has significant and positive effect on wages.

Training has the positive effect on wages. The male employees who are skilled (gender*training interactive category) have a positive effect on wages. A plausible for this is as compared to other categories this sector requires specific trainings and thus has significant impact on wages. Secondly employees of this sector are better trained in terms of quality and thus have positive and significant impact on wages.

Location of enterprise is also positively related with wages of the employees. The interactive term "Location*training" has significant and positive effect on wages.

\subsection{Community, Social and Personal Services}

The result show that age in community, social and personal services industry is highly significant and has a positive relationship with the log of monthly wages. Age square is significant and has negative sign which confirms an inverted U-shaped relationship between age and earnings. Marital status has significant and positive effect on wages. The impact of being male in Community, Social and Personal Services industry is positive and significant. Schooling is a significant variable with a positive effect on wages. Location is also positively related with wages of the employees. Results show that employees' of the industries located in urban areas are more advantaged than the employees' of the industries in rural areas.

\section{Conclusion and Recommendations}

Resource Development through vocational and technical education should be encouraged to promote the capacity of skilled manpower to adjust to changes in Labour demand. The study is an effort to assess the demographic factors in general and training and schooling in particular impact on wages. However the special emphasis of this study is training which is insignificant in most of the cases indicating shows poor quality of training and thus requires immediate attention.

Keeping in view the results of the study, some recommendations are as follows:

$>$ Training institutes should develop research and development capacities in their own respective fields to keep the supply of technicians/skilled workers of TEVT institutions matched, quantitatively and qualitatively, with the demand of industry.

> Initiate refresher programmes and crash programmes in latest methodologies for teachers. Upgrade existing technical colleges in terms of syllabus, equipment, facilities and teachers to meet modern challenges. An internal pool of trainers in selected technologies should be created by inducting master trainers from abroad.

$>$ Develop and establish national system of skills standardization, testing, certification, accreditation of institutions and equivalence.

$>$ Foster public-private partnership especially in technology-intensive field. Incentives can then be provided to private to establish technical institutes relevant to their own sector.

$>$ Much of success would depend on a demand-oriented vocational and technical education and reinforcement of general education with vocational education and training (VET) to vocationalize (polytechnicalize) the education in the country. There is a dire need of introducing a new model of vocational high school with the involvement of private sector. 


\section{Acknowledgement}

Authors are thankful to Dr Naheed Zia (FJWU) for her encouragement and giving very useful comments on the paper; however authors remain responsible for any errors in the paper.

\section{References}

Akram, M and Khan, F, J. (2007). Public Provision of Education and Government Spending in Pakistan. PIDE Working Paper Series No. 2007:40.

Anderson, Jock R. Feder, Gershon and Ganguly, Sushma. (2006). The rise and fall of training and visit extension: an Asian mini-drama with an African epilogue. Policy Research Working Paper Series with number 3928, World Bank.

Asian Development Bank. (2003). Labour Market Survey of Pakistan. Vocational and Technical Education Training Component of Pakistan. Manila: Asian Development Bank.

Caillods, Francoise. (1994). Converging Trends Amidst Diversity in Vocational Training Systems. International Labour Review, 13:2, pp. 241-257.

Card D. (2001). Estimating the Return to Schooling: Progress on Some Persistent Econometric Problems. Mountain Research and Development, Vol. 15, No. 3, pp.213-227.

Erickson L. C. and Jacoby M.S. (2003). The Effect of Employer Networks on Workplace Innovation and Training. Industrial and Labor Relations Review, Vol. 56, No. 2, pp. 203-223.

Hanushek E.A. and Kimko D. (2000). Schooling, Labor-Force Quality, and the Growth of Nations. The American Economic Review, Vol. 90, No. 5, pp.1184-1208.

Haq, Khadija. (2002). Human Development in South Asia-2002. Agricultural and Rural Development. Mehbub-ul-Haq Human Development Centre, Islamabad.

Haveman R. H. and Wolfe B.L. (1984). Schooling and Economic Well-Being: The Role of Nonmarket Effects. The Journal of Human Resources, Vol. 19, No. 3, pp.377-407.

Hussain' S. S, Byerlee, D and Paul W. Heisey. (1994). Impacts of the training and visit extension system on farmers' knowledge and adoption of technology: Evidence from Pakistan. Agricultural Economics, No. 1, Pages 39-47.

Hyder, A. (2007). Wage Differentials, Rate of Return toEducation, and Occupational WageShare in the Labour Market of Pakistan. MPRA Paper 2224, University Library of Munich, Germany.

IMF (FMI). (1998a). Cameroon: Statistical Appendix 1998. Washington, DC.

International Labour Organization. (1998). World Employment Report 1998-99: Employability in the Global Economy, How Training Matters. Geneva.

Kazmi1 W. S. (2005). Vocational Education and Skills Development: A Case of Pakistan. Pakistan Development Review, Vol. 44: 4.

Mayer, Jorg. (2000). Globalisation, Technology Transfer and Skill Accumulation in Low-Income Countries. United Nations Conference on Trade and Development (UNCTAD). Geneva: UNCTAD.

Munir, S. (2002). Vocational Education and Training (VET): Pakistan situation analysis (1959-2002) and Partnership needs to promote VET through research study. paper presented at Conference on "Structural Change in Vocational Education: Promotion of Vocational Education Partnership between Europe and West and Central Asian Countries Forum hotel, Alexanderplatz, Berlin.

O'Connor, David, and Maria Rosa Lunati. (1999). Economic Opening and the Demand for Skills in Developing Countries: A Review of Theory and Evidence.

Pakistan, Government of. (2005a). Pakistan Economic Survey 2004-05. Islamabad: Finance Division, Economics Adviser's Wing.

Shah, D. (2003). Country Report on Decentralization in the Education System of Pakistan: Policies and Strategies, Presented at UNESCO Seminar on Decentralization Policies and Strategies in Education, held at Buenos Aires, Argentina.

Simpson W. (1984). An Econometric Analysis of Industrial Training in Canada. The Journal of Human Resources, Vol. 19, No. 4, pp. 435-451.

Stolovitch, H.D. and Achi, Y. (1997). Use of Case Study Method to Increase Near and Far Transfer of Learning. Performance Improvement Quarterly, 10(2), 64-82. 
Tripathi, B. D. (2003). Current Strategies and Future Approaches for HRD in Agricultural Extension. Paper presented in the Regional Workshop on Operationalising Reforms in Agricultural Extension in South Asia.' May 6-8, 2003, New Delhi, India.

World Bank. (2002). Globalisation, Growth and Poverty. Washington, D. C.: WorldBank and Oxford University Press.

Table 1. Pakistan Standard Industrial Classification of All Economic Activities

\begin{tabular}{|l|l|}
\hline \multirow{2}{*}{ Industry } & Definition of Industries \\
\hline Agri & Agriculture, Forestry, Hunting and Fishing \\
\hline Mnq & Mining and Quarrying \\
\hline Manu & Manufacturing \\
\hline Egs & Electricity, Gas and Water \\
\hline Const & Construction \\
\hline Wsale & Whole Sales and Retail Trade and Restaurants and Hotels \\
\hline Tras & Transport, Storage and Communication \\
\hline Finance & Financing, Insurance, Real Estate and Business Services \\
\hline Community & Community, Social and Personal Services \\
\hline
\end{tabular}

Table 2. Variable Descriptions

\begin{tabular}{|l|l|}
\hline \multirow{2}{*}{ Variable } & Description \\
\hline Lnmwage & Log of monthly Wages \\
\hline Age & The age of the respondent expressed in years \\
\hline Agesq & Agesq \\
\hline Male & $=1$ if the individual is male; $0=$ female. \\
\hline Marital status & $=1$ if the individual is married; $=0$ otherwise \\
\hline Location of enterprise & $=1$ if the firm located in an urban areas; $=0$ otherwise \\
\hline Schooling & Number of years of schooling \\
\hline Schtrain & School-training \\
\hline Gentrain & Gender-training \\
\hline Loctrain & Location-training \\
\hline Training & Technical or Trade knowledge \\
\hline
\end{tabular}




\begin{tabular}{|c|c|c|c|c|c|c|c|c|c|c|c|c|}
\hline 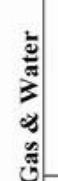 & 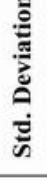 & 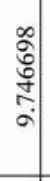 & 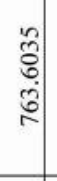 & 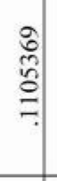 & 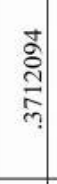 & 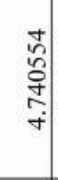 & $\begin{array}{l}\frac{2}{2} \\
\frac{a}{2}\end{array}$ & $\begin{array}{l}\infty \\
\stackrel{0}{0} \\
\dot{y}\end{array}$ & 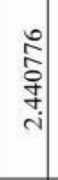 & $\begin{array}{l}\frac{a}{a} \\
\stackrel{+}{2}\end{array}$ & $\stackrel{\overline{0}}{\hookrightarrow}$ & 1 \\
\hline 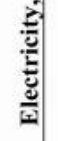 & $\frac{\bar{d}}{\frac{\pi}{z}}$ & $\begin{array}{l}\hat{\hat{b}} \\
\vdots \\
\infty \\
\infty\end{array}$ & 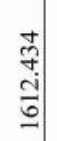 & 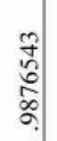 & $\begin{array}{l}\text { ڤे } \\
\hat{\omega} \\
\hat{\infty}\end{array}$ & 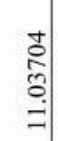 & 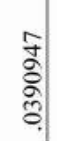 & 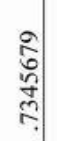 & $\begin{array}{l}\frac{\infty}{o p} \\
\frac{0}{p} \\
q \\
q\end{array}$ & $\begin{array}{l}\text { fे } \\
\text { ठे. } \\
\text { है }\end{array}$ & 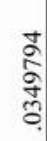 & 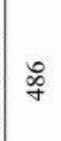 \\
\hline 핼 & 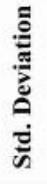 & $\begin{array}{l}0 \\
\hat{0} \\
\infty \\
= \\
=\end{array}$ & $\begin{array}{c}\infty \\
\stackrel{\infty}{a} \\
\stackrel{+}{\infty}\end{array}$ & 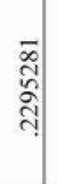 & 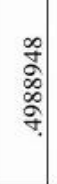 & 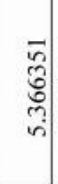 & $\begin{array}{l}2 \\
\vdots \\
0 \\
0\end{array}$ & $\begin{array}{l}0 \\
0 \\
0 \\
y \\
y\end{array}$ & 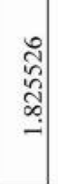 & $\begin{array}{l}\tilde{n} \\
\tilde{f} \\
\tilde{f}\end{array}$ & $\begin{array}{l}\frac{8}{0} \\
\frac{\mathrm{d}}{-1}\end{array}$ & 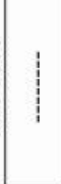 \\
\hline 馬 & $\frac{\text { हूँ }}{\Sigma}$ & $\begin{array}{l}\overline{\mathrm{c}} \\
\text { cे } \\
\text { pे }\end{array}$ & $\begin{array}{l}a \\
0 \\
0 \\
0 \\
0\end{array}$ & $\begin{array}{l}\frac{0}{3} \\
\frac{a}{2} \\
\end{array}$ & 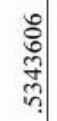 & $\begin{array}{c}\frac{\infty}{b} \\
\frac{6}{n} \\
? \\
n\end{array}$ & $\begin{array}{l}\frac{n}{7} \\
\frac{a}{0} \\
\end{array}$ & 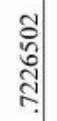 & $\begin{array}{l}\bar{n} \\
\hat{\vdots} \\
\vdots \\
\end{array}$ & $\frac{g}{d}$ & & đ̃ \\
\hline 晃 & 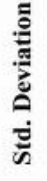 & $\begin{array}{l}\hat{\mathrm{n}} \\
\mathrm{m} \\
\mathrm{c}\end{array}$ & $\begin{array}{l}0 \\
0 \\
\vdots \\
0 \\
0 \\
0\end{array}$ & 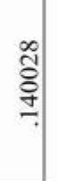 & 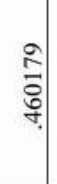 & 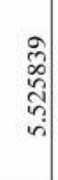 & 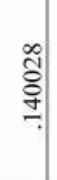 & $\begin{array}{l}0 \\
0 \\
0 \\
q \\
q\end{array}$ & 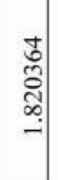 & 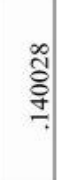 & 0 & 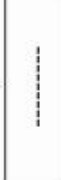 \\
\hline 竞 & 离 & $\begin{array}{l}\overrightarrow{7} \\
\text { bे } \\
\text { a }\end{array}$ & 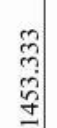 & $\begin{array}{l}\text { à } \\
0 \\
ః \\
\circ\end{array}$ & $\begin{array}{l}\text { L } \\
0 \\
0 \\
o ̂ n\end{array}$ & 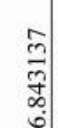 & $\begin{array}{l}\infty \\
0 \\
0 \\
0 \\
0\end{array}$ & 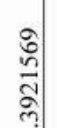 & 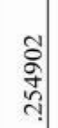 & 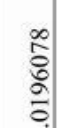 & 0 & $\overline{\text { in }}$ \\
\hline & 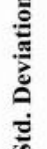 & 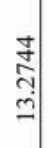 & $\begin{array}{l}\vec{q} \\
\vec{d} \\
\underline{d}\end{array}$ & 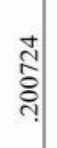 & \begin{tabular}{l} 
âे \\
\\
\multirow{े}{*}{}
\end{tabular} & 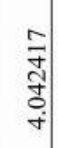 & $\begin{array}{l}a \\
2 \\
\frac{a}{a b} \\
b\end{array}$ & $\begin{array}{l}0 \\
\hat{0} \\
\text { ก. }\end{array}$ & 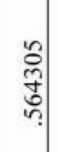 & $\begin{array}{l}\stackrel{\circ}{\circ} \\
\frac{\circ}{\circ 0} \\
\stackrel{\circ}{0}\end{array}$ & & 1 \\
\hline$\frac{\mathrm{g}}{\mathrm{v}}$ & $\frac{\bar{g}}{\Sigma}$ & 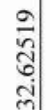 & 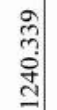 & 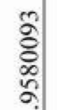 & $\frac{\hat{6}}{\hat{6}}$ & ते & $\begin{array}{l}0 \\
0 \\
0 \\
\vdots \\
0\end{array}$ & $\begin{array}{l}\vec{t} \\
\stackrel{0}{a} \\
\vec{a}\end{array}$ & $\begin{array}{l}9 \\
\text { âे } \\
\text { ồ }\end{array}$ & $\begin{array}{l}\text { : } \\
0 \\
\vdots \\
0\end{array}$ & & f \\
\hline & 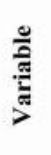 & 4 & $\begin{array}{l}0 \\
0 \\
0\end{array}$ & $\frac{0}{2}$ & $\begin{array}{l}\vec{n} \\
\bar{n}\end{array}$ & $\begin{array}{l}\overline{0} \\
\overline{0} \\
\bar{n}\end{array}$ & 咅 & $\begin{array}{l}\mathbf{5} \\
8 \\
0\end{array}$ & 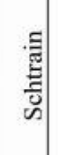 & 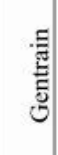 & & 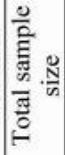 \\
\hline
\end{tabular}




\begin{tabular}{|c|c|c|c|c|c|c|c|c|c|c|c|c|}
\hline \multirow{2}{*}{ 歇 } & के & 辛 & $\begin{array}{l}0 \\
\stackrel{0}{0} \\
0 \\
\stackrel{\infty}{\infty} \\
\infty\end{array}$ & 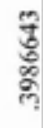 & 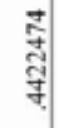 & 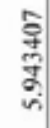 & \begin{tabular}{l}
8 \\
8 \\
0 \\
0 \\
\hdashline
\end{tabular} & $\frac{\hat{6}}{6}$ & $\begin{array}{l}\frac{\mathrm{z}}{\mathrm{z}} \\
\frac{\mathrm{a}}{\mathrm{a}} \\
\mathrm{d}\end{array}$ & 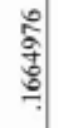 & $\begin{array}{l}0 \\
0 \\
0 \\
0 \\
0\end{array}$ & 1 \\
\hline & $\frac{\bar{g}}{\mathrm{~g}}$ & 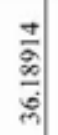 & $\begin{array}{l}0 \\
\stackrel{0}{ \pm} \\
\end{array}$ & ळ. & ผิ & $\frac{\hat{b}}{8}$ & $\begin{array}{l}0 \\
0 \\
0 \\
0 \\
0 \\
0\end{array}$ & $\begin{array}{l}\infty \\
\frac{\infty}{b} \\
\frac{\infty}{b}\end{array}$ & ชิ & 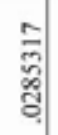 & : & $\stackrel{\infty}{R}$ \\
\hline \multirow{2}{*}{$=$} & के & : & 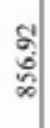 & $\begin{array}{l}\stackrel{8}{2} \\
\stackrel{\infty}{2}\end{array}$ & 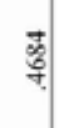 & 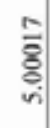 & $\frac{\mathrm{N}}{\mathrm{C}}$ & 응 & है & กี & : & ! \\
\hline & $\frac{a}{\frac{g}{2}}$ & 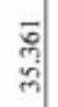 & $\begin{array}{l}\overrightarrow{7} \\
0 \\
0 \\
0\end{array}$ & fี & $\frac{6}{6}$ & $\begin{array}{l}\text { તે̆ } \\
\text { กี }\end{array}$ & 坴 & \% & สิ & $\begin{array}{l}\overline{0} \\
\text { ș }\end{array}$ & ริ & శ్ \\
\hline \multirow[b]{2}{*}{$E$} & 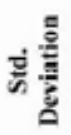 & 萏 & $\begin{array}{l}\frac{7}{7} \\
\frac{7}{n} \\
\infty \\
\infty\end{array}$ & 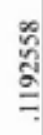 & ลิ & 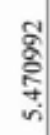 & $\begin{array}{l}\text { जे } \\
0 \\
0 \\
0 \\
\rightarrow\end{array}$ & $\frac{8}{8}$ & 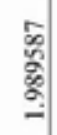 & 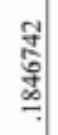 & $\begin{array}{l}0 \\
\hat{0} \\
\hat{6}\end{array}$ & \\
\hline & $\frac{\bar{E}}{\Sigma}$ & 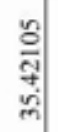 & $\begin{array}{l}\bar{q} \\
\stackrel{0}{0} \\
\stackrel{0}{2}\end{array}$ & 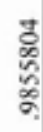 & مी & $\begin{array}{l}\text { जी } \\
\text { के } \\
\text { के }\end{array}$ & 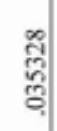 & 을 & $\frac{\frac{7}{n}}{\frac{\pi}{n}}$ & 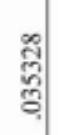 & 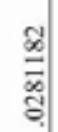 & $\begin{array}{l}\infty \\
\stackrel{\infty}{2}\end{array}$ \\
\hline \multirow{2}{*}{$\begin{array}{l}\text { हूँ } \\
\text { कू } \\
\text { हूँ }\end{array}$} & 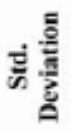 & $\stackrel{+}{\stackrel{0}{0}}$ & $\begin{array}{l}\infty \\
\stackrel{\omega}{0} \\
\infty \\
\otimes \\
\infty\end{array}$ & 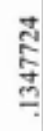 & 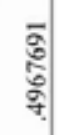 & 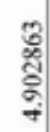 & 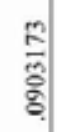 & तั & 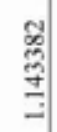 & 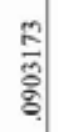 & 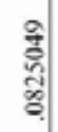 & \\
\hline & $\frac{\mathrm{E}}{\frac{\mathrm{E}}{2}}$ & 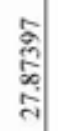 & 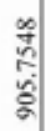 & $\frac{\%}{\frac{6}{0}}$ & 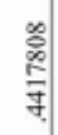 & : & $\begin{array}{l}\hat{\alpha} \\
\frac{\hat{\alpha}}{0} \\
\frac{0}{0}\end{array}$ & 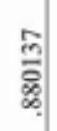 & 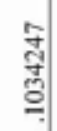 & $\begin{array}{l}\frac{2}{2} \\
\frac{8}{8}\end{array}$ & 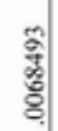 & $\underset{8}{8}$ \\
\hline \multirow{3}{*}{ 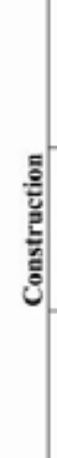 } & 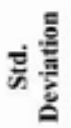 & $\begin{array}{l}\stackrel{+}{0} \\
\stackrel{Ð}{0} \\
=\end{array}$ & 常 & $\begin{array}{l}\text { สี } \\
\text { ळ. } \\
\stackrel{n}{-}\end{array}$ & 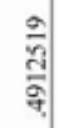 & 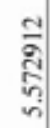 & 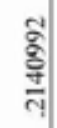 & $\frac{a}{\frac{a}{2}}$ & $\frac{\bar{s}}{\stackrel{\bar{a}}{\mathrm{i}}}$ & 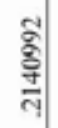 & $\begin{array}{l}\hat{8} \\
\hat{2}\end{array}$ & \\
\hline & $\frac{\sqrt{\tilde{E}}}{2}$ & 蒿 & $\begin{array}{l}\text { : } \\
\text { c. } \\
\text { â }\end{array}$ & $\frac{8}{\frac{1}{9}}$ & 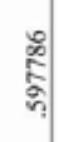 & 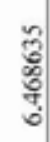 & 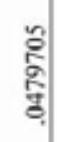 & $\begin{array}{l}\text { D } \\
\vdots \\
\vdots \\
\vdots\end{array}$ & 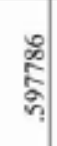 & $\begin{array}{l}0 \\
0 \\
\vdots \\
0 \\
0 \\
0\end{array}$ & ڤ్ & $\overline{\mathrm{a}}$ \\
\hline & $\begin{array}{l}\text { 릇 } \\
\frac{\text { 플 }}{\mathrm{n}}\end{array}$ & $<$ & : & $\frac{\mathrm{g}}{2}$ & $\overrightarrow{\mathrm{n}}$ & $\begin{array}{l}\overline{8} \\
\text { 总 } \\
\hat{n}\end{array}$ & 斯 & $\begin{array}{l}5 \\
\vdots \\
\xi\end{array}$ & 舄 & 昜 & 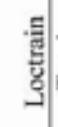 & $=$ \\
\hline
\end{tabular}




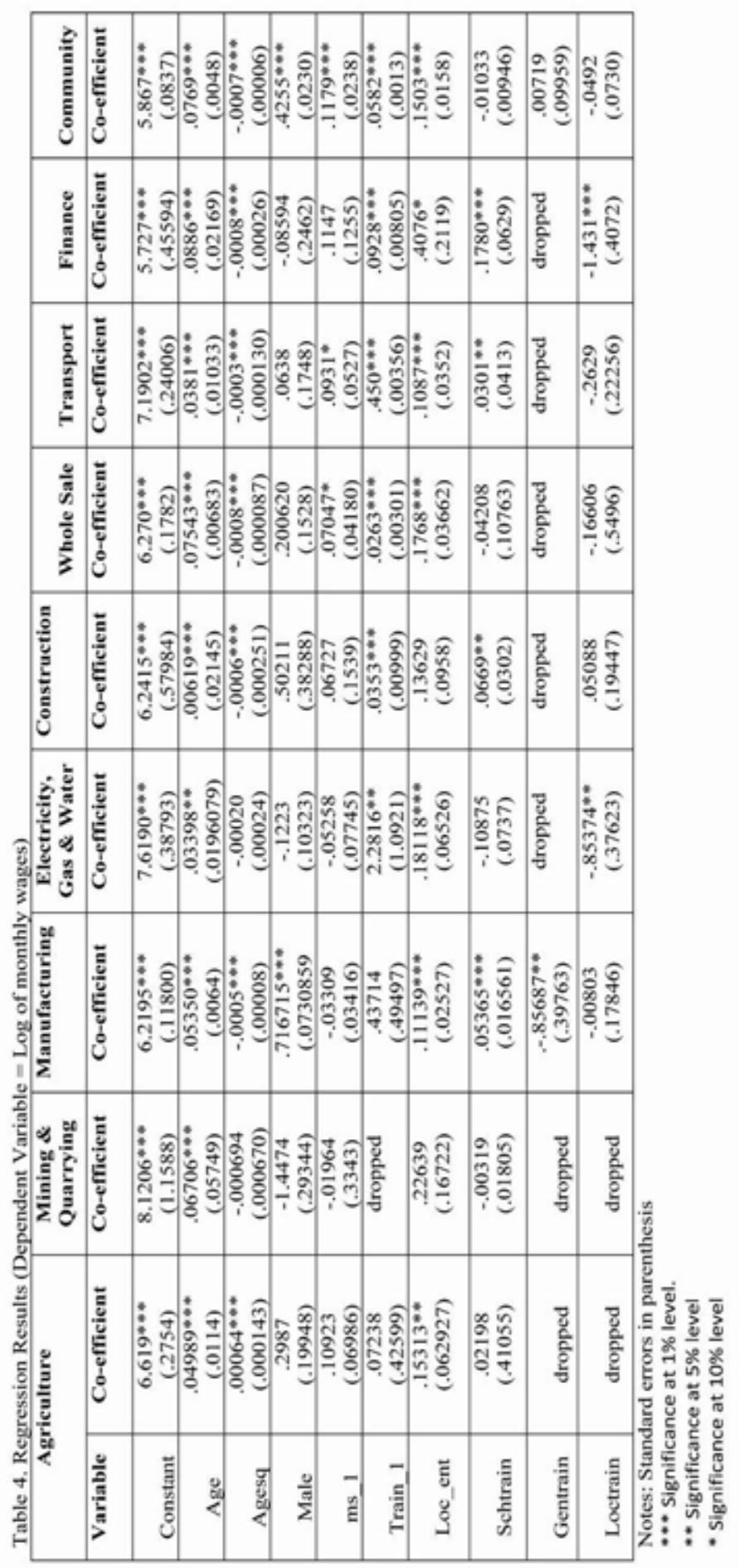

